\title{
Constitutional and Legal Regulation of the Process of Citizen Participation in the Affairs of the State in the Soviet Period
}

\author{
Sergei A. Shirobokov \\ Perm Institute of Economy and Finance, Kuybyshev street, 98A, Perm, Russia, 614010 \\ Email: shirobokovsa@gmail.com
}

\section{Doi:10.5901/mjss.2015.v6n3s6p169}

\begin{abstract}
Overall objective of presented article is the description of the constitutional establishment and legal regulation of the right of citizens on participation in an administrative office of the state in formation and development of the republican form of government in Russia. Also the purpose of scientific work it is necessary to consider development of the granted category of the right in the conditions of democratic and authoritative modes of board. One more research objective defines revealing of laws of development of the right of participation of citizens in a state administrative office together with development of the state form of the organization of territory, a combination of individual organizational-legal forms of participation to the collectivist. Constitution-legal regulation of participation of citizens in a state administrative office in the Russian Federation at the development present stage has not completely carried out continuity of separate legal institutes. In particular, there are no legal establishments concerning: participations in a society administrative office; the right to participate in discussion and acceptance of laws, and also decisions of nation-wide and local value (it is necessary to distinguish essentially from the right to participation in a referendum); the right of participation in national control; the right of participation in work of state structures; the right to criticize lacks of work of state structures. It is necessary to understand that there is an essential difference in directly to be realized in the decision of any state affair or only to have possibility somehow to affect bodies of the state which make the decision in a state affair. Formation of more accurate representation of necessity of legal definition and the expanded legal expression of a constitutional law of citizens on participation in a state administrative office will be promoted by researches of constitution-legal bases of participation of the person in a state administrative office in the Russian Federation in such directions as: studying of the constitutional principle of participation of citizens in an administrative office of the state and working out of characteristics of the constitutional bases of participation of citizens in a state administrative office.
\end{abstract}

Keywords: participation of citizens in managing the affairs of the state, constitutional rights, the complaints of citizens, government initiatives

\section{Introduction}

In order to objectively analyze the current state of implementation of the citizens of their constitutional right to participate in managing state affairs must carefully study the formation and psychogenetic development of this phenomenon in a single state - Russia. Pay attention to the cause-and-effect relationship of this social phenomenon. Moreover, it is necessary to take into account the social situation is around Russia, as well as the traditions and legal customs that had a significant influence on the development of public relations. Analyzing the constitutional and legal basis for participation of citizens in managing the affairs of the state in the Russian Federation is necessary to consider the content in terms of legal categories. The expression of the constitutional foundations of the right of citizens to participate in managing state affairs can occur in different ways: set the constitutional principle; is a constitutional tradition; is a constitutional right; used only when authorizing bodies of the state; allowed, but only in a narrow field and in accordance with well-defined procedures; is only a declaration; completely excluded. There is a unique situation where public bodies exercising public administration and in order to get the maximum result of their activities, participate in it ignores ordinary individual. Selfsame citizens use their capabilities in management requires registration consent on the part of the state. According to statistics, outreach by the public authorities, the use potential of the person that always gives a good result. Genuine participation of citizens in government - one of the main manifestations of democracy and the most important means of improving the work of the state apparatus. Any social institution suggests ability to create for every citizen of the conditions under which he could participate in the discussion of state laws, to elect their representatives, contribute to public law enforcement. Spend some analysis of the development process of legal participation of citizens in government, the effectiveness of different forms of application of this institution and the prospects for its dynamic development in the improvement of the state of civil society. 


\section{Methods and Materials}

As a methodological basis of research the system of philosophical knowledge with which help the basic criteria of requirements to scientific theories, to research of essence of the phenomena of public life are formulated. As a technique of the presented scientific research the general scientific dialectic method of knowledge and private-scientific methods following from it serves: system-structural, is concrete-sociological, technique-legal, historic-legal, a method of the comparative analysis. The author had been widely investigated the legislation of Russia in the field of legal regulation of participation of citizens in a state administrative office at various stages of development of the republican form of government. In work the method of comparative jurisprudence is widely used. With its help that general is shown, on the one hand, that is characteristic for forms and methods of participation of citizens in a state administrative office, and on the other hand, specificity of legal regulation of participation of citizens in a state administrative office, characteristic for the Russian state is designated. Also the author had been used an institutional method of research. On its basis the certain originality of ways and organizational-legal forms of participation of citizens in a state administrative office has been revealed; socially-legal value of participation of citizens in a state administrative office; specificity of the given legal institute which is simultaneously both the constitutional principle and a constitutional law, together with a certain guarantee of realization of other constitutional laws and freedom of citizens. At article writing the wide set of existing techniques of knowledge has been used. Their application has allowed the author to investigate considered objects in interrelation, integrity, comprehensively and objectively.

\section{Results}

Constitutional recognition of the rights of citizens to manage the affairs of the state in the early Republican period of the Russian Federation should be associated with the adoption of the first Constitution. The Constitution of the RSFSR in 1918 establishes the following elements of the mechanism of participation of citizens in managing the affairs of the state: (a) the introduction of workers' control; (b) advice to ensure the highest form of government workers; (c) the introduction of universal labor service; (d) provision of the workers and peasants of each nation the right to make an independent decision whether they want to, and on what basis to participate in the government and other state institutions; (e) prohibition of the exploiters to take seats in the government; (f) provision for genuine freedom of assembly workers, while recognizing the right of citizens of the Soviet Republic freely to hold meetings, rallies, marches, etc., available to the working class and the poor peasantry all buildings suitable for the public gatherings, complete with furniture, lighting and heating; $(\mathrm{g})$ the exercise of freedom of organization and action, rendering the workers and poor peasants all kinds of assistance, financial and otherwise, for their associations and organizations; (h) provision of all political rights of Russian citizens to foreigners residing in the territory of the Russian Republic for employment and belonging to the working class, or to not use the labor of others peasantry; (j) depriving individuals and individual rights groups, if they use them to the detriment of the socialist revolution; ( $k$ ) the establishment of active and passive suffrage; ( () voters who have sent a deputy to the Soviet have the right at any time to withdraw it and make new elections in accordance with the general situation (The Constitution (Fundamental Law) of the Russian Socialist Federative Soviet Republic, 1918).

Unfortunately, it should be noted the lack of detail of the process and forms of participation of citizens in managing the affairs of the state at the initial stage of the republican form of government. This fact can be explained by the fact that the administration of any kind of activity was not neglected, leading to a decrease in the efficiency of resource management. Constitution of the USSR in 1924 is devoted entirely to the public authorities of the union state, but, nevertheless, it is the text of some interest, since it specifies the organizational forms of managing complex state system: (a) the union republics; (b) congress of Soviets; (c) cohabitation; (d) cooperation; (e) representation; ( $f$ ) planning; ( $g$ ) session; (h) conciliation commission; (j) the Presidency; (k) meeting; (l) board; (m) supervision; ( $n$ ) protest, and so on. $d$. Note, however, that the participation of citizens in managing the affairs of the state is only implied, but not installed directly (The Constitution (Fundamental Law) of the Union of Soviet Socialist Republics, 1924).

Constitution of the RSFSR in 1925 to guarantee the existence of the dictatorship of the proletariat in order to suppress the bourgeoisie, abolishing the exploitation of man by man and the implementation of communism, in which there should be no division into classes nor state power. It was noted that all power within the Russian Socialist Federative Soviet Republic belongs to the councils of workers, peasants, Cossack and Red Army Deputies. From the point of view of the possibility of citizens to participate in managing state affairs established organizational forms, such as freedom of assembly, freedom to hold meetings, rallies, marches, etc., while providing at the disposal of the working class and the peasantry all buildings suitable for the People's Assembly premises. In order to ensure genuine freedom of association, the Russian Socialist Federative Soviet Republic has provided assistance to the workers and peasants for 
their associations and organizations. Participation of citizens in managing the affairs of the state involves the introduction of labor duties of all citizens and the establishment of universal conscription. The honorary right to defend the revolution by force of arms was granted only to workers; on unearned elements entrusted with the administration of other military duties. The overall organization of public administration was entrusted to the Council of People's Commissars of the Russian Socialist Federative Soviet Republic. Also clarifies the possibility of citizens to participate in managing state affairs by establishing each time the People's Commissariat of the Council of People's Commissariat convened periodically with representatives of its local organizations and businesses. Note fairly broad representation of the population in the Congress of Soviets of various levels: at the territorial and regional convenience: one delegate to 2,500 voters from district councils Congresses - one delegate to 12,500 inhabitants; in the district of convenience: one delegate for 60 voters from rural councils - one delegate for 300 inhabitants. Linking the participation of citizens in managing the affairs of the state to the electoral process should be noted that in addition to its own citizens active and passive suffrage is also endowed with all staying on the territory of the Russian Soviet Federative Socialist Republic of the Union of Soviet citizens of other republics. Based on the solidarity of workers of all nations, given all the political rights of foreigners residing in the territory of the Russian Socialist Federative Soviet Republic, and they had the right to work if belonged to the working class, as well as, or to not use someone else's work peasantry, but only on the basis of decisions of the Supreme Union of Soviet Socialist Republics. At the same time their own citizens were disenfranchised if they belong to one of these categories: (a) persons who use hired labor for profit; (b) persons living on unearned income, such as: interest on capital, profits from enterprises, receipts from property, etc.; (c) private traders, retail and commercial intermediaries; (d) spiritual ministers of worship of all faiths and persuasions, for which this occupation is a profession, the monks; (e) employees and agents of the former police, the special corps of gendarmes and security departments, members of the reigning house in Russia, as well as the person who led the work of the police, the gendarmerie and the secret police; (f) persons duly recognized as mentally ill or mentally unfit; $(\mathrm{g})$ persons convicted of crimes of his political rights for a fixed term of judicial sentence.

The Constitution of 1936, while maintaining the overall direction, makes quite fundamental amendments in the considered categories: (a) all power in the USSR belongs to the working people of town and country as represented by the Soviets; (b) in accordance with the interests of the workers and in order to develop the organizational initiative and political activity of the people, the citizens of the USSR are guaranteed the right to unite in public organizations: trade unions, cooperative associations, youth organizations, sport and defense organizations, cultural, technical and scientific societies, and the most active and conscious citizens in the ranks of the working class, the toiling peasants and intellectuals unite in the Communist Party of the Soviet Union, which is the vanguard of the working people in their struggle to build a communist society and is the leading core of all workers' organizations, both public and state.

That is, while maintaining the supplies power to citizens, there is a certain refinement - not all citizens, but only the working people of town and country, and then indirectly, through the institution of an MP and the organizational form of a "council". Participation of citizens in managing the affairs of the state focused on voting rights or collective participation in the public sphere in various forms, which implies a direct part in the management of state affairs. Democratic innovations in the development of the right to participate in managing state affairs can be attributed to the advent of the USSR Constitution of 1977 provisions fixing the possibility of more active participation of workers in the public life (The Constitution (Fundamental Law) of the Union of Soviet Socialist Republics, 1977).

Highlighted the main directions of development of the political system of Soviet society: the extension of socialist democracy; increasing the participation of citizens in managing the affairs of the state and society; improvement of the state apparatus; increase in the activity of public organizations; strengthening people's control; strengthening the legal framework for public and social life; expansion of publicity; permanent record of public opinion. The state with the broad participation of public organizations and labor collectives provides growth and equitable distribution of the social consumption funds. More concrete expression to the possibility of the participation of citizens in managing the affairs of the state we are in a certain order that citizens have the right to participate in government and public affairs, in the discussion and adoption of laws and decisions of national and local importance. These provisions is an innovative, specifies the notion of citizen participation in the affairs of the state. It is important that this right provides the ability to elect and be elected to the Soviets of People's Deputies and other elective state bodies, to take part in nationwide discussions and referendums, in people's control, in the work of state bodies, public organizations and local community groups, in meetings of labor collectives and the place of residence. As a positive opportunity to prioritize their identity in relations with the state we can find in the fact that every citizen has the right to make state bodies and public organizations for improving their activity, and to criticize shortcomings in their work. Officials are obliged in time to consider the proposals and statements of citizens, to reply to them and take the necessary measures. But the prosecution for criticism is prohibited. Persons persecuted for criticism, can be held liable. Of course, these provisions 
can be regarded as declarative, but in terms of the logic of the participation of citizens in managing the affairs of the state and the establishment of the new elements of the legal mechanism - this is the most effective guarantee of the established constitutional right. Noteworthy is the ability of individuals and the duty of the authorities in the form of Soviets build on the basis of collective, free, business discussion and resolution of issues, transparency, regular reporting to executive and administrative bodies and other bodies created by the Soviets before them and the community, involvement of citizens in participation in their work. Tips deputies and they create bodies should take into account public opinion, tabled in the citizens the most important issues of national and local significance, systematically inform them about their work and decision making. An important aspect is the peer review of civil and criminal cases in all courts, and in the court of first instance - with the participation of lay judges. The lay judges in administration of justice have all the rights of a judge. Similar articles were in the constitutions of all the Union and autonomous republics. The right to participate in managing state affairs was included in the category of political rights, and this rule applies to all forms (species) of the state and public life, including public administration as executive and administrative activities.

\section{Discussion}

We do not share the opinion of V.I. Novoselov (1979) is that the right to participate in government - one of the traditional rights of Soviet citizens, and that it is realized from the very first days of the Great October Socialist Revolution. Prior to the adoption of the Constitution of the USSR in 1977 was the right of citizens to participate in public administration exist, but it is likely to have been only moral and political right. But the practice of the first years of the new Constitution indicates that the rights contained therein citizens to participate in the management of state and public affairs, in the discussion and adoption of laws and decisions of national and local importance further raising public activity citizens, improving the handling of the device facing governance problems, expand and consolidate its relations with citizens (Novoselov, 1979). It is impossible not to recognize the fact that he himself administrative state apparatus, through the introduction of various forms of citizen participation in the affairs of the state, had the opportunity to familiarize themselves with public opinion and in accordance with that adjust their activities. Established a constitutional right to be a mere formality, without further legal clarification of legal personality and capabilities without the implementation of various organizational and legal forms by which state agencies are better able to study public opinion and on this basis to improve their work without increasing staffing levels, perform an increasing amount of increasingly complex work. Citizens, in turn, also acquire management skills more fully aware of their place in society and have an opportunity to make greater use in public and social practice their knowledge and abilities. Citizens may be interested in participating in the state and public administration. The results of sociological studies show that about $90 \%$ of those polled expressed a positive attitude towards social work in the local councils and their bodies, and only less than $5 \%$-negative (Perttsik, 1975). Many people at that time enjoy their right to participate in managing state affairs, using a variety of organizational forms and wasting your own time, completely disinterested, organically combining professional and social origin (Administrative apparatus of the socialist state, 1976).

Given the above it can be determined that the right of citizens to participate in government - a subjective right, reflecting both the personal interests of citizens and public, state interests, exercisable by the will of the citizens with certain objectives (Shirobokov, 2014). Given the importance of the right of citizens' participation in the management of the affairs of state should be analyzed and the very practice of using law to find out what are the problems faced citizen, whether there have been opposition to the individual process control. In the framework of the Constitution of the USSR in 1977 prioritized opportunities of citizen participation in governance of state affairs, was determined in the following options: (a) device management, at its discretion attracts (or not) to the citizens of their activities; (b) administrative apparatus required to use various forms of citizen participation in the affairs of the state; (c) device management should create conditions and provide opportunities to every citizen could participate in various forms in the management of state affairs; (d) the right of citizens and various organizational forms of citizen participation in the affairs of state are used by citizens, regardless of the will of the government.

Clarify the terminology by which expressed the relationship between citizens and the machinery of government. Here there are such things as "attraction", "use", "engagement", "realization of opportunities." The competence of the obligation to ensure the participation of citizens we can find not only in managing state affairs, but also in the territorial management, allowed solving many of the problems of interaction between state and individual. Of course, that governments were granted the right in its sole discretion to decide on the possibility of using individual organizational forms of citizen participation, taking into account the specific conditions (for example, through the departments of the executive committees of freelance and other units of management, for which indeed are selected and approved by the candidates) (Novoselov, 1979). Priority possible participation of citizens in managing the affairs of the state assumed 
clarify and define the organizational and legal forms of citizen participation in governance processes. It was formulated system that provides citizens with the opportunity to participate meaningfully in the management of public affairs at various stages of the process control in all industries and sectors of government. Options were offered the right of citizens' participation in state administration: (a) individual; (b) through civil society organizations; (c) by labor collectives; (d) through the bodies of public initiative.

There is a certain contradiction stated position on the part of state authorities on the priority of involving citizens in the management of state affairs and their detachment from the process. Realization of the right of citizens' participation in managing state affairs with the formal side does not provide for joint activities with the government, since the internal structure of government does not provide for the establishment and functioning of specialized units, aimed at implementing the interaction with the citizens of the state. You can make the assumption that as substitutes for these specialized structures were public education management teams themselves and party organs. It must be recognized that the organizational forms of citizen participation were clearly defined and have a real application, another thing; they were not enough, which, naturally, did not disclose all the features of the individual. The most widely used had the following organizational and legal forms of citizen participation in the affairs of the state: (a) participate in the discussion of draft legal acts of the government; (b) suggestions and criticism of shortcomings in the work of the administrative staff and led them to enterprises and institutions; (c) direct control of citizens of the work of the administrative apparatus, for national economic and socio-cultural activities; (d) discussion of governance issues at general meetings of citizens at their place of residence; (e) the work of citizens in the state apparatus volunteer; ( $f$ ) the work of citizens in public councils at enterprises of economic service and socio-cultural institutions.

Designated legal forms have certain advantages and practical applications, but at the same time, experts have noted a number of untapped opportunities and administrative omissions that do not allow full use of constitutional law and its regulatory capacity. For example, participation in the discussion of draft legal acts of public administration gave rise to many opinions and ideas that allow rationally, and using legal mechanisms (Dreyshev, 1977), but the absence of the order of the procedure is not possible to determine the form of discussions, the fixation of the views and opinions of accounting in the further work on the draft regulations - legal acts. Of particular importance this organizational form of participation acquired when it takes the regulations that are relevant to the general population, affecting the economic and social and cultural services, Draft Master Plan settlements, comprehensive programs in various fields, etc. (Yazev, 1970). Sufficiently relevant and useful form of citizen participation in managing state affairs was making suggestions and criticism of shortcomings in the work of the administrative staff and led them to businesses and institutions. This organizational form is considered as the most efficient, improve the state apparatus. Its use helped to strengthen control over the activities of the state apparatus, helps fight against bureaucracy and red tape was aimed at strengthening the socialist law and its application as noted citizens considered an important indicator of the political activity of citizens (Nikolaeva, 1961). Suffice it to say that the editors of all the newspapers in the country have been reported from 60 to 70 million letters, which is clear evidence of widespread use of this form of participation (Ponomarev, 1979). Another form of citizen participation in the affairs of the state is the direct control of citizens for the work of the administrative apparatus, for national economic and socio-cultural activities (Shahnazarov, 1974). Article 48 of the Constitution of 1977 determined the presence of empowering citizens' participation in the organizational-legal form. This form of participation has been studied and analyzed by many experts: Malkov (1963), Shorina (1981), B.M. Lazarev (1982), V.I. Turovtsev (1970). And furthermore, sets up a special legal mechanism to use this organizational form prescribed by the Constitution, which included: (a) monitoring, management and other activities; (b) participation in the hearing and discussion of reports of controls, employees of enterprises and institutions; (c) supervise the implementation of the control subjects addressed their specific requirements; (d) participation in public works parades and contests of industrial and socio-cultural institutions (Novoselov, 1979).

No less important role played and other legal forms of citizen participation in the affairs of the state. And therefore it is possible to formulate a conclusion that the constitutional right of citizens to participate in the management of state and social affairs has received wide support not only from the population, but also identified a positive attitude to this participation on the part of the state. Administrative staff has been focused on the full to ensure the full and highly efficient use of the capacity of citizens in solving public problems. Present a general understanding that the development of democracy associated with social opportunities of citizens in the political governance of the country. The Constitution (Fundamental Law) of the Russian Federation of 1978 also established as the unshakable foundations of the constitutional system of democracy, federalism, republican form of government, separation of powers. Was fixed position that all power in the Russian Federation belongs to the multinational people of the Russian Federation and that the people exercise state power through Soviets of People's Deputies, which constitute the political foundation of the Russian Federation, and directly. In this regard, all public authorities, formed in accordance with the law through democratic 
elections, and officials had to be accountable to the people. Were established organizational forms of popular participation of citizens in solving the most important issues of the state, such as the national discussion and popular vote (referendum). The direct participation of citizens in policy-making state in the administration of state and public affairs determined through their representatives from political parties, trade unions, youth and other public organizations and mass movements. Allows for the participation of labor collectives in discussing and deciding state and public affairs, in production planning and social development, training and placing personnel in the discussion and resolution of issues of management of enterprises and institutions, improve the working and living conditions, the use of funds intended for development of production, as well as for social and cultural purposes and financial incentives.

The main directions of development of the political system of the society were established: the extension of socialist democracy; increasingly broad participation of citizens in managing the affairs of the state and society; improvement of the state apparatus; increase in the activity of public organizations; strengthening people's control; strengthening the legal framework for public and social life; expansion of publicity; permanent record of public opinion. It was determined that the Russian Federation creates conditions and encourages economic initiative aimed at dynamic development of production, productivity growth and improving the welfare of society and every worker. The state aims to increase the real possibilities for use by citizens of their creative powers, abilities, and talents, to develop their personalities. Constitutionally, it was found that the citizens of the Russian Federation shall have the right to participate in managing the affairs of society and the state, either directly or through their representatives freely elected by direct universal and equal suffrage by secret ballot. In a separate article defines the right of public access to any post in state bodies in accordance with his training and without any discrimination.

Requirements imposed on candidates for public offices, explains the exceptional nature of the job. Organizational and legal forms of citizen participation in the affairs of the state were represented: the right to assemble peacefully and without arms; to hold meetings; marches; demonstrations and pickets on condition of prior notification of the authorities. Participation of citizens in managing the affairs of state also expressed right to send individual and collective appeals to state bodies and officials who, within its competence had to consider these appeals, take decisions on them and give a reasoned response within the statutory period, establishes the right of citizens to participate in the administration of justice as a folk or jurors. The constitutional right of citizens to participate in managing state affairs through participation in the electoral process did not apply to the mentally unfit to plead, and persons who are serving time in prison upon conviction. The electoral process included the right to nominate candidates for the deputies that belonged to labor collectives, public organizations, collectives of specialized secondary and higher educational institutions, groups of voters in the community and members of the military units. Participation of citizens in managing the affairs of the state in the territory shall be established by the local government. Local government could be carried out through public representative bodies - local councils of people's deputies, the relevant authorities - local authorities, local referendums, meetings (gatherings) of citizens, other territorial forms of direct democracy, as well as the bodies of territorial public self-government of the population. It provides all the citizens of an independent decision of local issues through their elected bodies or directly perform decisions of higher state authorities adopted within their competence, based on the interests of the population, based on assigned to governments material and financial resources. As part of the local councils of people's deputies elected from among the deputies standing committees for preliminary consideration of matters relating to local Councils, as well as to facilitate the implementation of the decisions of the Soviets, control over the activities of state bodies, enterprises, institutions and organizations. Recommendations of the standing committees of the local Soviets were subject to mandatory review by relevant government and public bodies, enterprises, institutions and organizations. On the outcome of the measures taken or needed to be communicated to the Commission within the prescribed period. Participation of citizens in managing the affairs of the state through constitutional justice was provided that all the courts of the Russian Federation were formed on the basis of the election of judges and lay judges. Justices of the peace were to be elected county population to which they have jurisdiction, for a period of five years. People's assessors of district (city) people's courts are elected at meetings of citizens at their place of residence or work by open ballot, and lay judges of the higher courts - the corresponding Councils of People's Deputies. The lay judges of military courts elected assemblies soldiers desk open vote. People's assessors are responsible to elected bodies or their constituents, had to report to them and could be recalled by them in accordance with the law. Continuing constitutional traditions found in the use of the provisions of the Constitution of the USSR in 1977 and the Constitution of the RSFSR in 1978, the Constitution of the Russian Federation in 1993 in Art. 32 also establish the right of citizens to participate in the management of state. In contrast to the previous expression of this right is already missing some elements, such as: (a) the right to participate in managing the affairs of the company; (b) the right to participate in the discussion and adoption of laws and decisions of national and local importance (to be fundamentally different from the right to participate in the referendum); (c) the right to participate in the national control; (d) the right to 
participate in the work of public authorities; (e) the right to submit to state organizations for improving their activity, and to criticize shortcomings in their work.

But it is the main purpose of the establishment of the constitutional rights of citizens is to establish a regulatory mechanism to ensure implementation of the constitutional rights of citizens to dispose of their public affairs (Grudtsyna, 2007). Effective mechanisms to serve the preservation and development opportunities for citizens will be the possibility to decide the affairs of state and of converting this opportunity into reality (Shirobokov, 2011). United by a common purpose of the system of constitutional norms and regulations is characterized by originality and method of controlling the interaction of all of its elements provides the optimal mode of implementation of this opportunity in the field of constitutional relations in the political management of society (Rechitsky, 1984).

\section{Conclusion}

Summarizing the above, we will try to draw some conclusions on the development of constitutional and legal provisions the right of citizens to participate in managing state affairs in the Russian Federation. Taking the approach as a real participation of citizens, which gives the maximum effect of the state form, we decided that at different stages of development of the state form completely differently expressed and to determine the degree of the participation of citizens in managing the affairs of the state. At the initial stage of the Republican form of government on the purposes determined by the kind of citizen participation in the affairs of the state through the introduction of universal labor service the destruction of parasitic strata of society and the organization of the economy. Next were formulated three components of social management also determines the strategy of citizen participation in managing state affairs: food production, the creation of essential goods and ensure the entire process of finances. Thought sounded sensible enough to provide all the political rights of foreigners residing in the territory of the Russian Socialist Federative Soviet Republic, provided that they belonged to the working class, while significantly limiting the political and civil rights of their own citizens for one simple reason, they belong to somebodies social class. Further development of the constitutional institution of citizens' participation in state administration is focused on voting rights or collective participation in the public sphere in various forms, which only involves the direct participation in the management of state affairs. More concrete expression to the possibility of citizens to participate in managing state affairs in the future is determined by what citizens have the right to participate in managing state and public affairs, in the discussion and adoption of laws and decisions national and local importance. In 1977-1978 these provisions is an innovative, specifies the notion of citizen participation in the affairs of the state, offers various options for realization of the right of citizens' participation in the management of state affairs. The real significance of the practical use of the results of the participation of citizens determines the mass character of taking part of the citizens in the processes of governance. The public authorities mentioned formation on the purposes of its activities to expand the real possibilities for use by citizens of their creative powers, abilities, and talents, to develop their personalities. Unfortunately, the democratic transformation 90 s did not serve to further the constitutional definition of the importance of citizen participation in the affairs of the state and therefore the Constitution of the Russian Federation in 1993, in contrast to the previous expression of this right already lacks many fundamental areas, such as the right to participate in the management of society; the right to participate in discussions and decision-making laws and national and local importance (to be fundamentally different from the right to participate in the referendum); the right to participate in the national control; the right to participate in the work of public authorities; right to make public organizations for improving their activity, and to criticize shortcomings in their work. One would assume that this gap should fill the legal regulation, enhance the legal capacity of citizens at the regional level, as noted in the individual subjects of the Russian Federation, but in most cases the participation of citizens in managing the affairs of the state in areas associated with those provisions, which are fixed in the federal Constitution. As a consequence underestimated the importance of this activity, which in some cases does not allow the effectiveness of the national development, which was calculated and that planned. Constitutional and legal regulation of citizen participation in the affairs of state in the Russian Federation at the present stage of development is not fully implemented the succession of individual legal institutions. In particular, there are no legal establishment relating to: participation in the management of public affairs; the right to participate in the discussion and adoption of laws and decisions of national and local importance (to be fundamentally different from the right to participate in the referendum); the right to participate in the national control; the right to participate in the work of public authorities; the right to criticize the shortcomings of the public authorities. It should be understood that there is a significant difference to be realized directly in the decision of a public affairs or just to be able to somehow affect the organs of the state, which shall decide on state business. A more clear idea of legal certainty and the need to expand the legal expression of the constitutional right of citizens to participate in managing the affairs of the state will contribute to the study of constitutional and legal bases of the individual participation in the affairs of state in the Russian Federation in 
areas such as: the study of the constitutional principle of citizen participation in the management of state affairs and development characteristics of the constitutional foundations of the participation of citizens in managing the affairs of the state.

\section{References}

Administrative apparatus of the socialist state. Part I. (1976). Moscow, MOW.

Grudtsyna, L.Y. (2007). Legal nature and form of interaction between civil society and the state. Law and Economics.

Dreyshev B.V. (1977). Legislating Soviet Government. (p. 65).

The Constitution (Fundamental Law) of the Russian Socialist Federative Soviet Republic (adopted V All-Russian Congress of Soviets in the meeting of July 10, 1918). Collection of Laws and Orders Workers' and Peasants Government of the Russian Federation.

The Constitution (Fundamental Law) of the Union of Soviet Socialist Republics (approved by the II-nd Congress of Soviets of the USSR on January 31, 1924). Legal Publishing House People's Commissariat.

The Constitution (Fundamental Law) of the Union of Soviet Socialist Republics (adopted at the seventh extraordinary session of the Supreme Soviet of the USSR Ninth Convocation October 7, 1977). Bulletin of the Congress of People's Deputies and Supreme Soviet.

Lazarev B.M. (1982). The citizen and management personnel. Moscow, MOW.

Lomakina V.F. (2014). Pressing questions of legal regulation of administrative responsibility in Russia. Administrative law and process. (pp.56-60).

Malkov,V.V. (1963). Public control and its role in the Soviet government. University of Moscow, Moscow, Russia.

Nikolaeva, L.A. (1961). Some issues of improving legislation and practice in dealing with complaints, applications and proposals of workers. Bulletin of the University of Leningrad.

Novoselov, V.I. (1979). Development of the right of Soviet citizens to participate in government. The Soviet state and the right, 11.

Perttsik, V.A. (1975). Basics rational organization of labor in local councils. Moscow, MOW.

Ponomarev, B.N. (1979). Real Socialism and its international importance. Communist.

Rechitsky, V.V. (1984). Constitutional guarantees the participation of Soviet citizens in public affairs. Law.

Shahnazarov, G.H. (1974). Socialist democracy (some questions of the theory). Moscow,MOW.

Shirobokov, S.A. (2014). Actual problems of legal regulation of the participation of citizens in managing the affairs of the state in the Russian Federation. Perm, PEE.

Shirobokov, S.A. (2011). Constitutional and legal aspects of participation of citizens in managing the affairs of the state in the Russian Federation. Perm, PEE.

Shorina E.V. (1981) Control over activity of state bodies in the USSR. Moscow, MOW.

Turovcev V.I. (1970). National control. Moscow, MOW.

Yazev, V.A. (1970). Industry and trade (legal issues). Moscow, MOW. 